\title{
Thermal resistance testing of standard and protective filtering military garment on the burning napalm mixture
}

\author{
Dusan S. Rajic ${ }^{1}$, Zeljko J. Kamberovic ${ }^{1}$, Radovan M. Karkalic ${ }^{2}$, Negovan D. Ivankovic ${ }^{3}$, Zeljko B. Senic ${ }^{4}$ \\ ${ }^{1}$ University of Belgrade, Innovation Center of Faculty of Technology and Metallurgy, Belgrade, Serbia \\ ${ }^{2}$ Technical Test Center, Belgrade, Serbia \\ ${ }^{3}$ University of Defence, Military Academy, Belgrade, Serbia \\ ${ }^{4}$ Military Technical Institute, Belgrade, Serbia
}

\begin{abstract}
Fires are an accompanying manifestation in modern weaponry use and in various accidents in peacetime. The standard military uniform is a primary barrier in protection of a soldier's body from all external influences, including the thermal ones which can cause burns. The minimum thermal resistance to the effect of burning napalm mixture (BNM) in individual uniform garment materials was determined, and found to be higher for simultaneous use of more materials one over another (the so-called sandwich materials), where the best thermal protection was exhibited by sandwich materials with an air interspace. The requirement for the thermal resistance of the material of the filtrating protective suit (FPS) to the effect of BNM ( $\geq 15 \mathrm{~s}$ ) was fully met. The highest thermal resistance was demonstrated by the FPS whose inner layer was made of polyurethane foam with active carbon. The FPS thermal resistance to the effect of BNM was found to be proportional to water vapor permeability through this garment mean, and inversely proportional to air permeability.
\end{abstract}

Keywords: thermal resistance, RCB protection, physiological suitability, burning napalm mixture.

\author{
SCIENTIFIC PAPER \\ UDC 623.4:355:66 \\ Hem. Ind. 67 (6) 941-950 (2013) \\ doi: 10.2298/HEMIND120817011R
}

Available online at the Journal website: http://www.ache.org.rs/HI/

Fires are a side effect of the use of conventional weapons. They frequently occur in different types of accidents. Extreme cases of thermal effects occurring during nuclear explosions and in the moment of projectile (laborated with napalm mixture) explosion, where the incendiary napalm jellied mixture disperses through the space in the form of different size drops. Although the use of napalm and nuclear weapons is forbidden by international conventions, these weapons are still in the arsenals of many armies in the world, so the possibility of their use is not excluded in practice [1].

Soldier uniforms are made of the highest quality fabrics combined with flame retardants. Most flame retardant textiles are designed to reduce the ease of ignition and also reduce the flame propagation rates. Conventional textiles can be rendered flame retardant by chemical after-treatments as co-monomers in their structures, or by use of flame retardant additives during extrusion. High performance fibers with inherently high levels of flame and heat resistance require the synthesis of all aromatic structures, but these are expensive and used only when performance requirements justify cost [2].

Correspondence: N.D. Ivankovic, MA, University of Defence, Military Academy, Pavla Jurisica-Sturma 33, 11000 Belgrade, Serbia.

E-mail: negovan.ivankovic@gmail.com

Paper received: 17 August, 2012

Paper accepted: 25 January, 2013
During the burning napalm mixture (BNM) effects, the soldier's clothing, which is supposed to protect his body, is exposed to thermal effects which causes it to burn through, thus leaving the skin burnt. Military burn injuries on the battlefield can be attributed to three causes: flame and thermal threats, incidental or secondary hazards and accidents. Threat-generated burns result from the direct employment of a flame and thermal weapons. Incidental or secondary burns result from flame and thermal weapons or other threats (i.e., ballistic, blast, directed energy) that ignite battlefield combustibles, including clothing or equipment that can also present a burn hazard. Accidents comprise the remaining burn hazard. The degree of skin damage depends on many factors, such as the heat source strength, time of heat exposure, affected skin surface, heat transfer mode, age and health condition of an injured person, and the anatomical structures of the skin that has been exposed to the effect of heat [1]. However, it is generally considered that the first degree burns can be expected in humans in temperature zones of 40 to $45^{\circ} \mathrm{C}$, second degree burns between 45 and 60 ${ }^{\circ} \mathrm{C}$, and third degree above $60{ }^{\circ} \mathrm{C}$. Burns of the second and third degree directly disable soldiers to continue fighting and perform other activities, and they require treatment. It is considered that, in a possible world war in the future, burns would take between 40 and $50 \%$ of 
all injuries, which indicates the considerable importance of studying this problem.

Burns are a significant cause of morbidity and mortality in the military environment in combat and peacetime, but the impact of clothing on burns is not addressed adequately in the medical literature. Historically, even in combat, burn injuries more often result from the ignition of battlefield combustibles due to accidents or secondary flame effects in the environment, than from direct flame and thermal threats [3]. In addition, the specific cause of casualties and fatalities has been difficult to characterize in terms of burn injuries because many were documented as involving multiple trauma and explosions. Until recently the flame threat had generally been categorized as relatively low for the individual soldier, and due to the increased use and exposure to fuels, burn injuries had been more prevalent for both Navy and Air Force personnel. However, during Operation Iraqi Freedom, the use of improvised explosive devices (IEDs) against USA ground forces has become prevalent. The IEDs serve not only as ignition points for battlefield combustibles, but have been enhanced to include fuels, making them a direct battlefield threat to the soldier and increasing the likelihood of burn injuries. Kim [4] has reviewed the characteristics of several battlefield threats and combustibles, estimating that the values of the heat flux of thermobaric, incendiary and flame weapons, and JP-8 fuel converge to a common heat flux of about $2.0 \mathrm{cal} \mathrm{cm}^{-2}$ $\mathrm{s}^{-1}$ over time. Since the likelihood of survival of a direct hit from a flame and thermal weapon is low based on the initial ignition temperatures and known blast effects, and the fact that many burn injuries result from the secondary effects of the environment, a thermal flux of $2.0 \mathrm{cal} \mathrm{cm}^{-2} \mathrm{~s}^{-1}$ was selected as most representative of a military fire hazard that is survivable if exposure time is short. Appropriately developed protective clothing should provide critical seconds of increased escape time to distance oneself from the flame hazard and thereby provide a lesser, but survivable exposure time [4].

The first line of defense against flame assault is the clothing system outer-layer, which in every configuration tested is flame resistant. Each additional clothing under-layer adds insulation and increases protection time [5]. It is assumed that thermal energy is absorbed as latent heat of fusion when the material melts. When melted onto the skin, this heat will then be delivered to the skin and superficial tissues in a continuing manner as it solidifies again, potentially increasing the thermal dose delivered and tissue damaged in heating and cooling phases. Although the physical processes will undoubtedly occur, there is little quantitative information in the literature to support the view that this is a notable contributor to the burn - the rate of heat release to the tissues in the solidifying process may be quite slow and capable of being dissipated by conduction and blood flow.

Most clothing materials will ignite if the temperature is high enough and potentially deliver thermal energy from this process to the skin and underlying layers. The total energy liberated by combustion of material will not necessarily be transferred to the skin and the proportion of energy transferred will depend on the material, undergarment, air gaps and any pretreatment.

Viscose rayon is formed from wood pulp and is a filamentous form of cellulose. Cotton, wool and viscose rayon, are not thermoplastic and will not shrink in response to heat. At $245^{\circ} \mathrm{C}$ for untreated wool and 350 'C for cotton and viscose rayon, a carbonaceous "char" is formed, with volatile liquids and gases generated, before combustion at 600,350 and $420{ }^{\circ} \mathrm{C}$, respectively.

Synthetic material fibers are stronger than most natural fibers and clothing manufactured from them can be made lighter and warmer by incorporating air spaces. This characteristic enables wet synthetic clothing to dry more quickly but, when burning, is a more open structure and may burn rapidly and completely. Mixtures of synthetic and natural materials can behave detrimentally - the non-thermoplastic material may support the burning of thermoplastic material within its char and propagate the combustion. This is termed "scaffolding" and although demonstrated experimentally with clothing samples, appears to be unusual in combat burn simulations. The favorable qualities of lightness, warmth, permeability to moisture vapour, quick drying and durability, mean that these materials are ideal for combat personnel in adverse conditions. Specialized fabrics such as Nomex ${ }^{\mathrm{TM}}$ or Kevlar ${ }^{\mathrm{TM}}$ are thermoplastic, but will not soften until 275 and $340{ }^{\circ} \mathrm{C}$ and they melt at 375 and $560{ }^{\circ} \mathrm{C}$, respectively. These materials will not burn until temperatures reach more than 500 and $550{ }^{\circ} \mathrm{C}$, respectively, but their action as sole protection against burns is limited by other factors such as thermal conductivity. A fire retardant material with high thermal conductivity such as Nomex ${ }^{\mathrm{TM}}$ will require an effective inner insulating layer to prevent conduction through the materials to the skin surface. Nomex $^{\mathrm{TM}}$ as an outer layer with an equal mixture of wool and cotton as undergarment was found to be significantly better protection than Nomex ${ }^{\mathrm{TM}}$ as outer and inner layers against flame exposure over $1.75 \mathrm{~s}$ duration. The extent of any air gap is not made clear, but a two-layer Nomex ${ }^{\mathrm{TM}}$ system is also significantly better than a single layer of Nomex ${ }^{\mathrm{TM}}$ for any tested duration.

The fire retardance of textiles can be enhanced by additives or coatings. The mechanisms of action can 
differ, but the aim is to prevent combustion or to increase the magnitude of the thermal energy required to cause combustion. These mechanisms may include the production of a barrier to oxygen, or stabilizing intermediate pyrolysis products and forming a char, thus preventing the formation of flammable, volatile products.

A well trained army, equipped with quality means for personal protection, could reduce losses to a minimum and provide functional operability at the shortest possible time, even after a surprise attack, using nuclear weapons or napalm. It is therefore necessary to study the thermal resistance of various protective materials, with constant requirements for the improvement of utility performance. Depending on the degree of radioactive, chemical and biological (RCB) contamination, tactical tasks, the need for easier movement, performing tasks of different difficulty and other important factors, the selection of the appropriate personal protective means of isolating or filtering type is being done. Isolating means have good protective properties and bad physiological properties. Their purpose is to protect the body, legs and arms from RCB contamination. A number of means for body protection is based on isolating materials. These include protective coveralls, light protective overgarments, protective gloves, protective boots and protective socks. They are made of different materials: elastomers (e.g., butyl rubber) and thermoplastics $\left(\right.$ Tyvek $^{\circledR}$, polyethylene, etc.). They are used in conditions of RCB weapons usage, in the process of decontamination, reconnaissance, stay on the contaminated soil, etc. when it is necessary to remain protected for a few hours [6-10].

Garments based on filtrosorption materials are physiologically better suited than those based on isolating materials. They provide much longer stays in contaminated zones, and beyond, as well as performing tasks of higher physical and mental level. In addittion to this, these means have good protective properties in respect to the effect of RCB agents. When it comes to personal body protection during long stay on the land and in an atmosphere contaminated with RCB agents, as well as during carrying out difficult tasks in a warm environment, the filtering protective suit (FPS) has no alternative [11]. The materials of which FPS is made, as opposed to the materials of isolating means, are permeable to air and water vapor, which means that they are physiologically more suitable, which reduces the possibility of heat stress in carrying out assigned tasks [12-15].

Protective garment means, even in the phase of their development, need to meet a whole series of tactical-technical requirements that must be fulfilled before their adoption in armaments and military equipment.
When it comes to protective thermal characteristics of protection means for bodies, they are required to protect the user from burning napalm mixture (BNM) for at least $15 \mathrm{~s}$ [16].

The aim of this study is to determine which type of standard military clothing and FPS, as a representative of filtering type protective RCB clothing, will best consolidate in itself an acceptable level of effective thermal protection of BNM, and at the same time provide satisfactory functional characteristics, i.e., adequate physiological response of human organism. All these activities are carried out in respect to the relevant requirements in the field of standardization of test conditions [17].

\section{EXPERIMENTAL}

\section{Investigation of thermal characteristics of suit materials}

The method of testing BNM effects [15] was based on an apparatus consisting of:

- Material sample holders

- Ring for fixing the material sample

- Ring for separation of the material

- Tripod on which the sample holder is mounted

- Metal pans for the protection from BNM which burns the sample

- Measuring head with temperature sensors

- Amplifier assembly

- Power supplies

- Computer, printer, plotter

- Chronometer.

The measuring head had the following characteristics:

- Temperature measurement range: $0-100{ }^{\circ} \mathrm{C}$

- Allowed overdraft (no damage) to $200{ }^{\circ} \mathrm{C}$

- Decomposition within the measurment range: $0.5^{\circ} \mathrm{C}$

- Accuracy of the measured values: $1 \%$ of range

- The time constant of response: $2 \mathrm{~s}$

- The number of sensors (measuring points): 7.

The test method for resistance of materials to the effect of BNM involves three test procedures:

- Timing of burning through sample material

- Temperature measurement on the opposite side of the material exposed to the effect of BNM

- Visual evaluations of material behavior.

\section{Time of sample material burning through}

Napalm mixture (about $2 \mathrm{~cm}^{3}$ ) is applied by syringe in the middle of the sample material. Then the mixture is being burned and time of burning measured. Time of burning represents the time from the moment of ignition of the applied napalm mixture to the face of material, to the point of its appearance on the opposite side. 
Testing time of burning is monitored visually and measured by chronometer.

\section{Measurement of temperature}

The purpose of this method is to determine the thermal properties of materials, i.e., measuring the temperature on the opposite side of the sample material exposed to the effects of $2 \mathrm{~cm}^{3}$ of BNM (temperature is measured on the side of the body). Seven sensors of the measuring head measure temperature as a function of time - during the effects of BNM and cooling of the materials once the effect of flame is over (Figure 1).

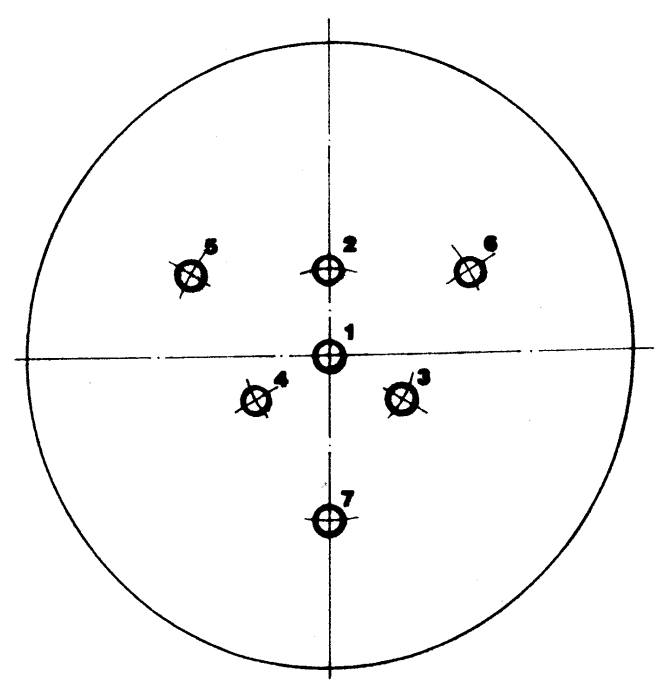

Figure 1. Layout and identification of measurement sensor.

The measurement head is first set on the sample holder according to Figure 2, and then test material of selected variant (single or sandwich materials with and without an air space between layers) is set on the head. It is particularly important to point out the materials used in this study were previously exposed to different climatic influences [17-19]. When testing the sandwich materials, the measuring head is placed respectively: a sample of one soldiers' garment material, the ring for material samples separation (if sandwich materials are tested), a sample of the second material of outer garment or protective RCB means (Figure 2). The number of samples and the ring are in the desired and realistic range. A drop of a previously made napalm mixture (volume of $2 \mathrm{~cm}^{3}$ ) is applied to the outer material sample by syringe and it is then ignited. At the time of napalm mixture ignition, the temperature sensors are activated and software data processing is performed. After $200 \mathrm{~s}$ (or any other time in the interval time from 0 to $300 \mathrm{~s}$, which is governed by the software package) the curves for all temperature sensors, or for the temperature sensor that detects the highest temperature, are drawn on the screen.

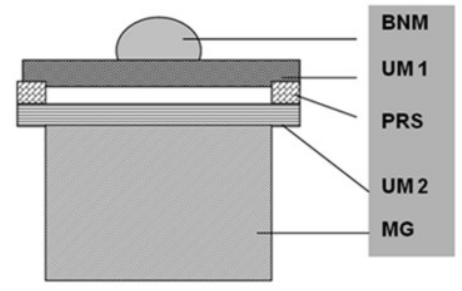

Legend

$\mathrm{BNM}$ - a drop of napalm mixture,

UM1 - material sample 1, $\mathrm{PRS}-\mathrm{a}$ ring for materials separation,

$\mathrm{UM} 2$ - material sample 2, $\mathrm{MG}$ - measurement head.

Figure 2. Procedure for testing of sandwich materials on effect of BNM.

The obtained temperature data are processed by computer and reported in tabular or graphic form. Tabular data and obtained curves of temperatures in function of time for each of the seven sensors, define the thermal characteristics of tested material and offer the possibility of determining the time until appearance damage of skin in form of $1^{\text {st }}, 2^{\text {nd }}$ or $3^{\text {rd }}$ degree burns [11], i.e., give the opportunity to define the procedures and time that are at disposal to a soldier to neutralize the effects of BNM.

\section{Visual evaluations of material behavior}

Visual evaluations of material behavior during effect of BNM refer primarily to the assessment of material self-extinguishing (do the material extinguish after the cessation of firing effect). The characteristics of flame, combustion products (fumes, gases, particles, etc.), as well as burning behavior of materials and degree of material degradation after effects of BNM are visually monitored.

\section{Tested samples of means for the body protection}

In experiments the following FPS means are used: filtering protective suit - model 2 (OFZ-M2), manufacturer „Trayal“, Kruševac, Serbia, filtering protective suit, model 2 PUR (OFZ-M2PUR), manufacturer "Trayal“, Kruševac, Serbia, and filtering protective suit, model 00 (OFZ-M00), manufacturer „Mile Dragic Production", Zrenjanin, Serbia.

\section{The tested materials}

In the experimental study of thermal characteristics the materials used for production of a set of the uniform M03, manufacturer "Mile Dragic Production", Zrenjanin, Serbia, were as follows: camouflage undershirt (hereinafter referred to as an undershirt), camouflage shirt (hereinafter referred to as a shirt), camouflage jacket (hereinafter: blouse) and different variants of the material testing (Table 1).

Test variations of material resistance to the effects of BNM, i.e., their thermal performances, refer to the real image of wearing the soldier garment and FPS as representative means for personal RCB body protection. Testing variants of individual materials, sandwich materials and sandwich materials with air interspace are given in Table 2 . 
Table 1. Material characteristics; $\bar{X}$-mean value, SD-standard deviation

\begin{tabular}{|c|c|c|c|c|}
\hline No. & $\begin{array}{c}\text { Material of garment and } \\
\text { protective means }\end{array}$ & Raw material composition & $\begin{array}{c}\text { Thickness, mm } \\
(\bar{X} \pm S D)\end{array}$ & $\begin{array}{l}\text { Surface mass, } \mathrm{g} / \mathrm{m}^{2} \\
(\bar{x} \pm S D)\end{array}$ \\
\hline 1 & Undershirt & Cotton $100 \%$ & $0.55 \pm 0.03$ & $168 \pm 0.2$ \\
\hline 2 & Shirt & Cotton $67 \%$, polyester $33 \%$ & $0.42 \pm 0.02$ & $212 \pm 0.4$ \\
\hline 3 & Blouse & Cotton $50 \%$, polyester $50 \%$ & $0.47 \pm 0.04$ & $263 \pm 0.3$ \\
\hline \multirow[t]{2}{*}{4} & FPS-M2 & Outer layer: cotton $67 \%$, polyester $33 \%$ & $0.45 \pm 0.08$ & $185.3 \pm 0.4$ \\
\hline & & $\begin{array}{l}\text { Inner layer: the spheres of active carbon material } \\
\text { (AUM) on the fabric }\end{array}$ & $0.85 \pm 0.04$ & $300.7 \pm 0.2$ \\
\hline \multirow[t]{2}{*}{5} & FPS-M2PUR & Outer layer: cotton $67 \%$, polyester $33 \%$ & $0.48 \pm 0.03$ & $190.1 \pm 0.3$ \\
\hline & & $\begin{array}{c}\text { Inner layer: activated carbon powder traped into PUR and } \\
\text { sandwich of two light fabrics }\end{array}$ & $0.8 \pm 0.04$ & $340.1 \pm 0.5$ \\
\hline \multirow[t]{2}{*}{6} & FPS-M00 & Outer layer: cotton $67 \%$, polyester $33 \%$ & $0.42 \pm 0.05$ & $215.3 \pm 0.6$ \\
\hline & & $\begin{array}{c}\text { Inner layer: AUM glued to the fabric and covered with } \\
\text { another cloth }\end{array}$ & $0.78 \pm 0.05$ & $380.2 \pm 0.5$ \\
\hline
\end{tabular}

Table 2. Variations of test materials

\begin{tabular}{|c|c|c|}
\hline No. & Materials & Test variant \\
\hline 1 & Individual materials & Camouflage undershirt (undershirt) \\
\hline 2 & & Camouflage shirt (shirt) \\
\hline 3 & & Camouflage jacket (blouse) \\
\hline 4 & & FPS M2 \\
\hline 5 & Sandwich materials & Undershirt + FPS-M2 \\
\hline 6 & & Undershirt + shirt + FPS-M2 \\
\hline 7 & & Undershirt + shirt + blouse + FPS-M2 \\
\hline 8 & Sandwich materials with air interspaces (AI) & Undershirt + Al + FPS-M2 \\
\hline 9 & & Undershirt + shirt + Al + FPS-M2 \\
\hline 10 & & Undershirt + Al + shirt + blouse + FPS-M2 \\
\hline 11 & & Undershirt + shirt + Al + blouse + FPS-M2 \\
\hline 12 & & Undershirt + shirt + blouse + Al + FPS-M2 \\
\hline 13 & & Undershirt + Al + shirt + Al + blouse + FPS-M2 \\
\hline 14 & & Undershirt + Al + shirt + blouse + Al + FPS-M2 \\
\hline 15 & & Undershirt + shirt + Al + blouse + Al + FPS-M2 \\
\hline 16 & Sandwich materials with three air interspaces (AI) & Undershirt $+\mathrm{Al}+$ shirt $+\mathrm{Al}+$ blouse $+\mathrm{Al}+\mathrm{FPS}-\mathrm{M} 2$ \\
\hline
\end{tabular}

\section{RESULTS AND DISCUSION}

The air permeability refers to the amount of air (expressed in cubic meters) that is let through a square meter of fabric per $\min \left(\mathrm{m}^{3} \mathrm{~m}^{-2} \mathrm{~min}^{-1}\right)$. This is measured at the prescribed pressure difference, in standard environmental conditions. The permeability of air through clothing is one of its most important functional characteristics. It is affiliated with the size and distribution of pores of textile materials. In terms of higher outer temperature and at higher body loads, it creates a large amount of heat and sweat, so a higher air permeability of the clothing material is needed to improve the physiological suitability. This is in contrast with the increasing degree of protection against RCB agents, where the lower air permeability is desirable.
The results of air permeability of standard war uniform are shown in Table 3.

It can be seen that the uniform undershirt has the highest air permeability in the standard military kit, and military pants have the lowest air permeability. Table 4 shows the results of air permeability through an FPS sandwich of materials.

All FPS sandwich materials have higher air permeability of the blouse and pants, which is a very important fact considering that the FPS can be used as a standard war uniform. The highest air permeability was exhibited by FPS-M00. 1.2 times greater than the permeability of FPS-M2 and 1.8 times greater than the permeability of FPS-M2PUR.

Analysis of the obtained results of air permeability testing (Tables 3 and 4 ) on one hand, and the thermal resistance on BNM effect (Figure 3) in FPS and 16 test 
Table 3. Air permeability of standard war uniform

\begin{tabular}{|c|c|c|c|c|c|c|c|c|}
\hline \multirow{3}{*}{$\begin{array}{l}\text { Part of uniform } \\
\text { Blouse }\end{array}$} & \multicolumn{8}{|c|}{ Air permeability, $\mathrm{m}^{3} \mathrm{~m}^{-2} \mathrm{~min}^{-1}$} \\
\hline & \multicolumn{3}{|c|}{$\begin{array}{l}\text { From the face side to the reverse } \\
\text { side of the face }\end{array}$} & \multirow{2}{*}{$\frac{\bar{X} \pm S D}{2.48 \pm 0.02}$} & \multicolumn{3}{|c|}{$\begin{array}{c}\text { From the reverse side of the face } \\
\text { to the face side }\end{array}$} & \multirow{2}{*}{$\begin{array}{c}\bar{X} \pm S \\
2.59 \pm 0.02\end{array}$} \\
\hline & 2.51 & 2.47 & 2.48 & & 2.57 & 2.61 & 2.60 & \\
\hline & 2.47 & 2.50 & 2.48 & & 2.60 & 2.58 & 2.58 & \\
\hline \multirow[t]{2}{*}{ Pants } & 2.09 & 2.09 & 2.08 & $2.09 \pm 0.01$ & 1.42 & 1.34 & 1.36 & $1.36 \pm 0.03$ \\
\hline & 2.11 & 2.08 & 2.11 & & 1.38 & 1.40 & 1.35 & \\
\hline \multirow[t]{2}{*}{ Shirt } & 11.96 & 11.98 & 11.92 & $11.94 \pm 0.03$ & 11.75 & 11.81 & 11.78 & $11.76 \pm 0.03$ \\
\hline & 11.94 & 11.92 & 11.98 & & 11.72 & 11.74 & 11.75 & \\
\hline \multirow[t]{2}{*}{ Undershirt } & 184.17 & 185.21 & 184.72 & $184.82 \pm 0.6$ & 182.45 & 182.56 & 182.29 & $182.38 \pm 0.2$ \\
\hline & 185.25 & 184.13 & 185.49 & & 181.98 & 182.55 & 182.47 & \\
\hline
\end{tabular}

Table 4. Air permeability of sandwich materials; VT-a type of treatment (I- untreated, II-after exposure to climate and after test-exploitation investigations); $A$-from the face side to the reverse side of the face; $B$-from the reverse side of the face to the face side

\begin{tabular}{lccc}
\hline \multirow{2}{*}{ Model FPS } & & Air permeability, $\mathrm{m}^{3} \mathrm{~m}^{-2} \mathrm{~min}^{-1}$ & $\mathrm{~B}(\bar{X} \pm S D)$ \\
\cline { 2 - 4 } FPS-M2 & VT & $\mathrm{A}(\bar{X} \pm S D)$ & $7.2 \pm 0.8$ \\
& $\mathrm{I}$ & $7.2 \pm 0.8$ & $7.1 \pm 0.8$ \\
FPS-M2PUR & $\mathrm{II}$ & $7.1 \pm 0.7$ & $4.9 \pm 0.6$ \\
& $\mathrm{I}$ & $4.9 \pm 0.4$ & $4.9 \pm 0.5$ \\
FPS-M00 & $\mathrm{II}$ & 8.0 .5 & $8.8 \pm 0.7$ \\
& $\mathrm{I}$ & $8.3 \pm 0.7$ & $8.7 \pm 0.8$ \\
\hline
\end{tabular}

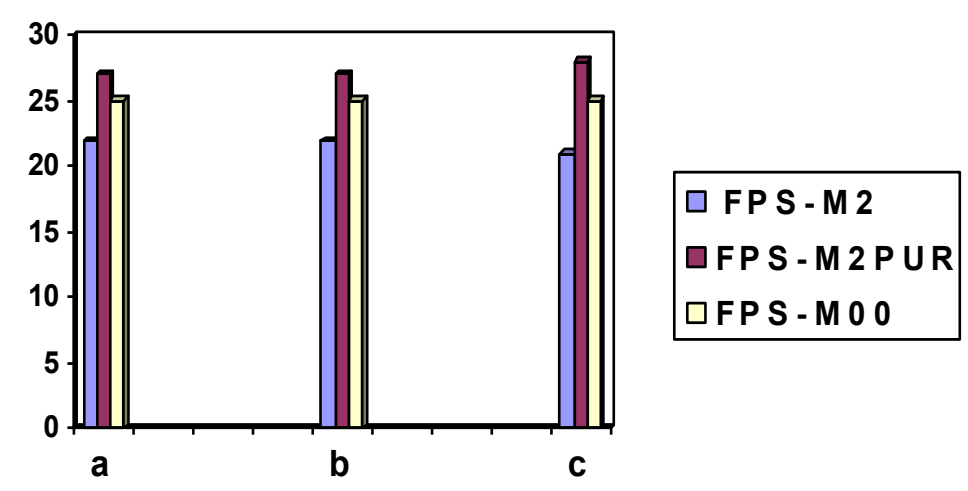

Figure 3. Burning through time (s) at the effect of BNM on the outer and inner layer of the FPS sample after three types of treatment: $a$ - untreated samples, $b$-samples after the climate impact and c-samples after exploitation.

combinations of materials and garment means (Figure 4 ) on the other, established that these two parameters are inversely proportional.

The flow of steam or sweat from the surface of human skin to the surroundings is one of the most important parameters for prediction of the use value of a protective garment. The human body uses a very efficient cooling mechanism, which activates when there is no sufficient heat release, physiologically by respiration and dry heat stream. This is particularly expressed during great physical exertion or high temperature environment conditions, which occur in the case of BNM effects. In this case, the sweat glands of the skin surface begin to exude sweat along with the water which evaporates and thus the skin pushes away excess heat into the environment. The water vapor travels from the skin through garment in ambient air due to vapor pressure difference on the skin surface and the partial pressure of water vapor in the surrounding air. The results of the examination of water vapor permeability of FPS sandwich materials are shown in Table 5.

The obtained values for water vapor permeability of FPS suit materials indicate that all materials were of satisfactory quality in terms of sweat removal from the user's body. FPS-M00 had the highest water vapor permeability, 1.2 times more than water vapor permeability of the FPS-M2 and FPS-M2PUR. 
Table 5. The water vapor permeability of sandwich materials

\begin{tabular}{lcc}
\hline Model FPS & Water vapor permeability, $\mathrm{g} / \mathrm{m}^{2} \cdot 24 \mathrm{~h}(\bar{X} \pm S D)$ \\
\hline FPS-M2 & I & $3131.5 \pm 0.8$ \\
& II & $3129.2 \pm 0.7$ \\
FPS-M2PUR & I & $3125.5 \pm 0.9$ \\
& II & $3120.3 \pm 0.9$ \\
FPS-M00 & I & $3825.6 \pm 0.7$ \\
& II & $3820.3 \pm 0.6$ \\
\hline
\end{tabular}

Analyzing the test results of water vapor permeability (Table 5) on one hand, and the FPS thermal resistance at BNM effect (Figure 3) on the other hand, their proportional interdependence could be determined. It can be concluded that the materials of all three FPS models are permeable to water vapor, which contributes to a better exchange of heat generated in the body with the surroundings and a better transfer of sweat fluid compared to the isolating materials and the materials of less water vapor permeability. Results of FPS materials resistance testing to the effects of BMN are shown in Figure 3.

From Figure 3 it can be noticed that the time of burning through the outer and inner layer of untreated FPS was highest for FPS-M2PUR (27 s) and lowest for FPS-M2 (22 s). Exposed to BNM effects, material samples of all three FPSs burned and there was intense smoke.

Time of burning through the outer and inner layer of samples exposed to climatic influences $[13,14,16]$ at all three FPSs samples is the same as at untreated samples, from which it can be concluded that climate changes do not negatively affect the thermal resistance of the FPS samples.

The time of burning through the outer and inner layer of exploited FPS samples is the largest for FPS M2PUR (28 s), and lowest for FPS-M2 (21 s). Exposed to BNM effects, material samples of all three FPSs burn and there is intense smoke.

Since the tactical-technical requirements for FPS$-M 2$ indicated that this mean must not be burnt through for at least $15 \mathrm{~s}$ during BNM effects, the results in $\mathrm{Fi}$ gure 3 show that this requirement is satisfying for all three FPS models. Figure 3 shows that in all test conditions (untreated samples, after climate change and after exploitation) the highest thermal resistance during BNM effect was found for FPS-M2PUR, then FPS-M00 and finally FPS-M2. This is logical, because the lowest air permeability was found for FPS-M2PUR.

The FPS materials are made to have some protective properties in respect to the effect of BNM which is defined through the regulations on the quality of this mean. However, processing of flame retardants considerably increases the costs, because it is more difficult to meet some other tactical-technical requirements, for example camouflaging.

Figure 4 shows the results of determining material resistance to the effects of BNM by measuring temperature on the opposite side of the material regarding the side of BNM effects: individual materials, sandwich materials and sandwich materials with an air interspace. The obtained temperatures have been correlated with the appropriate degree of burns. Figure 4 shows an overview of temperature rise on the opposite side of the specimen from the moment of the critical temperature $\left(40{ }^{\circ} \mathrm{C}\right)$, when burns occur for the time base of 7 cycles of measurements of each sensor.

Based on the obtained results (Figure 4) it can be seen that in all tested variants of individual materials, the time before $1^{\text {st }}$ degree burns appear was very short (1 s), which means that the structural characteristics of the materials of soldiers' garments and FPS-M2 (primarily raw composition, thickness and porosity) do not influence protection. The time elapsed until $2^{\text {nd }}$ degree burns appear was different compared to the test version and it is longest for FPS-M2 (9 s), followed by undershirt and blouse (4s) and at the end shirt (2 s). The longest protection time of the variation with FPS$-\mathrm{M} 2$ is caused by the maximum thickness of this material, and the shortest time of the shirt variation is related to the minimum thickness. Variations of mate-
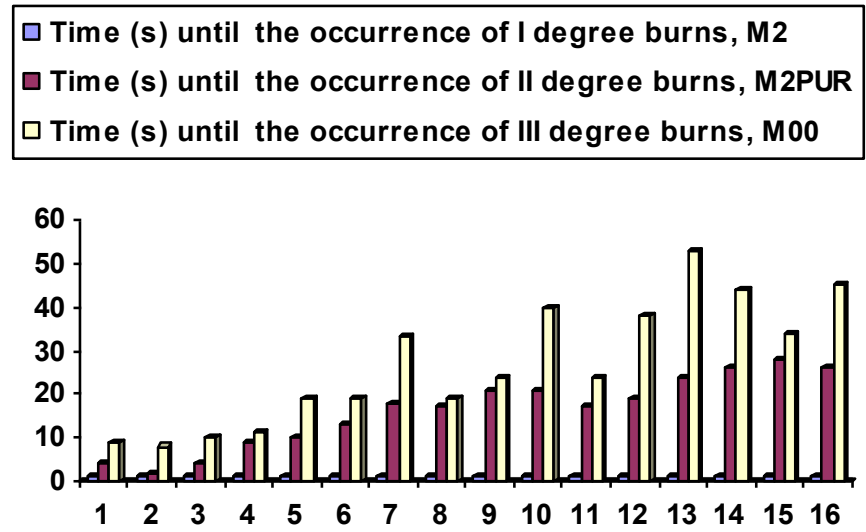

Figure 4. Occurrence time of $1^{\text {st }}, 2^{\text {nd }}$ and $3^{\text {rd }}$ degree burns at the effect of BNM on 16 types of test materials and their combinations. 
rial of undershirt and blouse have the same time protection which is $4 \mathrm{~s}$. Cotton fibers, of which undershirt is made, give the same resistance to the effects of BNM as a mixture of polyester/cotton, which is built into the blouse, due to better thermal properties of cotton relative to polyester fiber, and because of the structural characteristics of these two variants (thickness, surface mass and porosity). Thelapsed time before the occurrence of $3^{\text {rd }}$ degree burns is slightly larger than the elapsed time of before the occurrence of $2^{\text {nd }}$ degree burns. It can be said that the individual materials of undershirt, shirt and blouse do not have good thermal protection. A soldier affected by the influence of BNM, would get $2^{\text {nd }}$ degree burns in a short period of time ( 4 s) and would be unable to fight.

As for the results of sandwich combination resistance to the effects of BNM, the time before $1^{\text {st }}$ degree burns occur remained at the level of $1 \mathrm{~s}$, but the time before the occurrence of $2^{\text {nd }}$ degree burns was significantly longer than the time of the individual materials (Figure 4). Also, the time before the occurrence of $3^{\text {rd }}$ degree burns was significantly longer than the time of protection responsible for the burns of 2 nd degree. Each additional layer extends the time of protection. For variants: undershirt + FPS-M2, undershirt + shirt + + FPS-M2 and undershirt + shirt + blouse + FPS-M2, the elapsed times before the occurrence of $2^{\text {nd }}$ degree burns were 10, 13 and $18 \mathrm{~s}$ respectively, and the elapsed times before the occurrence of $3^{\text {rd }}$ degree burns for the same variants were 19, 19 and $33 \mathrm{~s}$. The results clearly show that the blouse, as an additional layer, significantly increases the resistance of the sandwich material to the effect of BNM. Based on it, it can be concluded that the overall thickness of the layers of garment over a certain thickness significantly increases the time of protection.

Since it is known that the air interspace (Al) is an insulator which represents a barrier to the heat passing through, it is expected that the existence of air spaces increases the resistance of the sandwich material to the heat passing through (i.e., to the effect of BNM). Figure 4 shows that variations of the test material with Al show a longer time of protection until the occurrence of the $2^{\text {nd }}$ and $3^{\text {rd }}$ degree burns in relation to variations of the sandwich material without Al. Also, Figure 4 shows that the time elapsed until the occurrence of the $2^{\text {nd }}$ degree burns in variants with and without $\mathrm{Al}$, or variant 5 (undershirt + FPS-M2) and 8 (undershirt + Al + FPS-M2) was 10 and $17 \mathrm{~s}$, respectively. In variant 6 (undershirt + shirt + FPS-M2) and variant 9 (undershirt + shirt + Al + FPS-M2) the amount of time was 13 and $15 \mathrm{~s}$, and for variant 7 (undershirt + shirt + + blouse + FPS -M2) and variant 9 (undershirt + Al + + shirt + blouse + FPS -M2) 18 and 21 s. A similar difference is observed in the analysis of time elapsed until occurrence of the 2 nd degree burns. Results of the resistance testing of sandwich materials with two Al on BNM effect suggests further increased resistance to heat transmission and better protective properties than the presence of only one Al. Comparison of variants of the same sandwich materials with one and two Al shows that additional Al extends the times before the occurrence of $2^{\text {nd }}$ degree burns for 7 to $11 \mathrm{~s}$ (variants 9 and 10 with an $\mathrm{Al}$ and variants 13 and 14 with two Al). Differences in the obtained times are higher when looking at the occurrence of burns of $3^{\text {rd }}$ degree. The results show that variants of sandwich materials with three Al do not lead to increased resistance in relation to variants of sandwich materials with two Al, which should be checked in future. It is noteworthy that in the present study, Al was always of the same thickness $(1 \mathrm{~mm})$ and that this was a constant thickness along the entire surface of the test material variants.

Although it is said that $2^{\text {nd }}$ degree burns disable soldiers for any action, it should be understood conditionally. The BNM drops that reach the human body have different distribution, density and size. Also, there are differences depending on which body parts are affected by BNM, and differences in percentage involvement. The size of the affected body area is very important, as well as whether the vital organs are in those areas or not. Despite these facts, the obtained elapsed times until the occurrence of $2^{\text {nd }}$ degree burns, give chance to an affected person (on a lesser or greater extent by BNM drops), to react adequately and eliminate or reduce the risk of injuries caused by BNM effects.

\section{CONCLUSION}

Each additional clothing under-layer adds insulation and increases protection time. Tests performed with various samples show differences in performance that are likely due to differences in material type and garment construction.

Testing the thermal resistance of three FPS models when affected by a burning napalm mixture in a set time of at least $15 \mathrm{~s}$ was carried out, where it was determined that this requirement is fully met in all models. The highest thermal resistance was demonstrated by FPS-M2PUR (produced from polyurethane foam and activated carbon), then FPS-MOO (woven fabric and spherical carbon adsorbent), and finally FPS-M2 (fabric and spherical carbon adsorbent). A proportional relationship between the thermal resistance of FPS to the effect of BNM and water vapor permeability through this garment mean has been determined, and inverse proportionality in relation to air permeability, which had been expected.

This study determined the thermal resistance of soldiers garment (undershirt, shirt and blouse) and FPS$-\mathrm{M} 2$ during the effect of BNM, by measuring the tem- 
perature on the opposite side from that which has been treated by a drop of BNM, and by measuring the time before occurrence of burns of $1^{\text {st }}, 2^{\text {nd }}$ and $3^{\text {rd }}$ degree. The thermal resistance of single and sandwich materials (more garment means worn one over the other at once) with one, two and three air interspaces was determined.

Individual materials show the lowest thermal resistance to the effects of BNM, followed by sandwich materials. Sandwich materials with air interspace provide the best thermal protection because the air presents the insulation to heat passing through. When exposed to the effect of a BNM, all variants of test materials experience a short time (1 s) until temperature causes the $1^{\text {st }}$ degree burns. However, the critical time at which materials protect a user from the effects of BNM is the elapsed time before the $2^{\text {nd }}$ degree burns appear, because the garment user is disabled to perform any task at that very time. When wearing sandwich materials, the time before the $2^{\text {nd }}$ degree burns occur is long enough for the user to take appropriate steps to eliminate or minimize the harmful consequences caused by the influence of BNM. This critical time may be longer if an amount of BNM affects a smaller area of a body or if vital organs stay intact.

\section{Acknowledgements}

Ministry of Education, Science and Technological Development of the Republic of Serbia support this work, Grant No. TR34034 (2011-2014).

\section{REFERENCES}

[1] A.D. McLean, Burns and Military Clothing, J. R. Army Med. Corps 147 (2001) 97-106.

[2] F. Hull, J. Gambill, A. Hansche, G. Agni, J. Evangelista, C. Powell, M. Auerbach, J. Dillon, Ö. Arnas, Engineering an undergarment for flash/flame protection, Proceedings, ASME-IMECE 2011-63888, Denver, CO, 2011.

[3] D.W. Tucker, S.A. Rei, Soldier Flame/Thermal Hazard Assessment, Natick/TR-99/039L, U.S. Army Soldier and Biological Chemical Command, Natick, MA, 01760-5020.

[4] I.L. Kim, Battlefield Flame/Thermal Threats or Hazards and Thermal Performance Criteria, TR-00/015L, U.S. Army Soldier and Biological Chemical Command, Natick, MA, 01760-5020.

[5] G. Song, R.L. Barker, H. Hamouda, A. V. Kuznetsov, P. Chitrphiromsri, R.V. Grimes, Modeling the Thermal Protective Performance of Heat Resistant Garments in Flash Fire Exposures, Textile Res. J. 74 (2004) 1033-1040.
[6] The Military Medicine Series, Part I. Warfare, Weaponry, and the Casualty, Volume 5: Conventional Warfare: Ballistic, Blast, and Burn, Office of the Surgeon General, U.S. Department of the Army, Washington, DC, 1990.

[7] T.E. Bowen, R.F. Bellamy (Eds.), Ch. 3, Burn Injury, Emergency War Surgery, $2^{\text {nd }}$ US Rev. of The Emergency War Surgery NATO Handbook, U.S. Department of Defense, Washington, DC, 1989, pp. 35-56.

[8] A Report on the Thermal Protective Performance (TPP) and the Pyroman Evaluation for the U.S. Army Soldier Systems Command, Center for Research on Textile Protection and Comfort (T-PACC), College of Textiles, North Carolina State University, Raleigh, NC, 1999.

[9] D. Jackson, An overview of thermal protection, Protective Clothing Conference, Clemson University, SC, 1998.

[10] A.R. Horrocks, Developments in flame retardants for heat and fire resistant textiles - the role of char formation and intumescences, Polym. Degrad. Stability $\mathbf{5 4}$ (1996) 143-154.

[11] Z. Senic, M. Jevremovic, R. Karkalic, Determination of the resistance of soldiers garment means to the effect of burning napalm mixture, OTEH, 2007.

[12] R. Karkalic, Optimization of thin film sorption carbon materials built into the CBRN means in function of the protective characteristics and physiological fitness, Ph.D. Thesis, Military Academy, 2006.

[13] EN ISO 12894:2001, Ergonomics of the thermal environment - Medical supervision of individuals exposed to extreme hot or cold environments, CEN-European Committee for Standardization.

[14] EN ISO 9886:2004, Ergonomics - Evaluation of thermal strain by physiological measurements. CEN-European Committee for Standardization.

[15] SORS 6704:1988, RCB body protection - Test method for resistance of materials to the effects of napalm mixture, Direction for Standardization, Codification and Metrology, Ministry of Defense, Republic of Serbia.

[16] I. Mekjavic, E. Banister, J. Morrison, Environmental Ergonomics, Taylor \& Francis, London, 1987.

[17] SORS 0187:1979, Testing of external influences on the armament and military equipment, Raised temperature, Method 102. Direction for Standardization, Codification and Metrology, Ministry of Defense, Republic of Serbia.

[18] SORS 0188:1991, Testing of external influences on the armament and military equipment, Lowered temperature, Method 103. Direction for Standardization, Codification and Metrology, Ministry of Defense, Republic of Serbia.

[19] SORS 0186:1991, Testing of external influences on the armament and military equipment, Sudden temperature changes, Method 101. Direction for Standardization, Codification and Metrology, Ministry of Defense, Republic of Serbia. 


\section{IZVOD}

\section{TESTIRANJE TERMIČKE OTPORNOSTI STANDARDNE I FILTRIRAJUĆE ZAŠTITNE VOJNIČKE UNIFORME NA GORUĆU NAPALM SMEŠU}

Dušan S. Rajić ${ }^{1}$,̌eljko J. Kamberović ${ }^{1}$, Radovan M. Karkalić ${ }^{2}$, Negovan D. Ivanković ${ }^{3}$, Željko B. Senić $^{4}$

${ }^{1}$ Univerzitet u Beogradu, Inovacioni centar Tehnološko-metalurškog fakulteta, Beograd, Srbija

${ }^{2}$ Tehnički opitni centar, Beograd, Srbija

${ }^{3}$ Univerzitet odbrane, Vojna akademija, Beograd, Srbija

${ }^{4}$ Vojnotehnički institut, Beograd, Srbija

(Naučni rad)

Požari su prateća manifestacija kod upotrebe naoružanja u savremenom ratu i u slučajevima nastanka različitih akcidenata u mirnodopskim uslovima. Standardna vojnička uniforma predstavlja primarnu prepreku u zaštiti tela vojnika od svih spoljnih uticaja, uključujući i termičke koji mogu da izazovu opekotine. Cilj ovog rada je da utvrdi koja vrsta standardne vojničke odeće i odela filtrirajućeg zaštitnog (OFZ) kao predstavnika zaštitne RHB odeće filtracionog tipa će u sebi najbolje da objedini prihvatljivi nivo efikasne termičke zaštite od goruće napalm smeše (GNS) uz istovremeno obezbeđenje zadovoljavajućih funkcionalnih karakteristika tj. adekvatnog fiziološkog odgovora organizma čoveka. Sve ove aktivnosti su sprovedene uz poštovanje relevantnih zahteva na polju standardizacije uslova ispitivanja. Utvrđena je najmanja termička otpornost na delovanje GNS kod pojedinačnih odevnih materijala uniforme, veća kod istovremenog korišćenja više materijala jednih preko drugih (tzv. sendvič materijala), a najbolju termičku zaštitu pružaju sendvič materijali sa vazdušnim međuprostorom (VP). Taktičko-tehnički zahtev za termičku otpornost materijala OFZ na dejstvo GNS ( $\geq 15 \mathrm{~s}$ ) kod sva tri ispitivana modela u potpunosti je ispunjen. Najveću termičku otpornost je pokazao OFZ-M2PUR koji je urađen na bazi poliuretanske pene i aktivnog uglja, zatim OFZ-M00 na bazi tkane tkanine i sferičnog ugljeničnog adsorbenta i konačno OFZ-M2 na bazi tkane tkanine i sferičnog ugljeničnog adsorbenta. Utvrđena je proporcionalna zavisnost između termičke otpornosti OFZ na dejstvo GNS i propustljivosti vodene pare kroz ovo odevno sredstvo, a obrnuta u odnosu na propustljivost vazduha.
Ključne reči: Termička otpornost • RHB zaštita • Fiziološka podobnost • Goruća napalm smeša 